\title{
Vivências culturais paulistas da Ilustração Luso-brasileira
}

\section{Paulistas’ $^{\prime}$ cultural experiences of Portuguese - Brazilian enlightenment}

Resumo: O objetivo do presente trabalho é o de recuperar as vivências que, entre a religiosidade tradicional e o laicismo, os paulistas tiveram da ilustração luso-brasileira, nos seus aspectos de cultura erudita. Entre as manifestações musicais, as realizações arquitetônicas e de artes plásticas, e as produções literárias e historiográficas, procura-se avaliar o significado do iluminismo em uma área da Colônia Brasil ainda pouco estudada nessa dimensão.

Palavras-chave: Inovação. Tradição. Laicidade. Centralização.

\begin{abstract}
The main purpose of this article is to retrieve the paulistas' experiences of Portuguese Brazilian enlightenment in its erudite cultural aspects, ranging from the traditional religiosity to secularism. Among musical, architectural and visual arts achievements as well as literary and historical productions, it seeks to assess the significance of enlightenment in an area of Portuguese America up to now not enough studied in its cultural dimension.
\end{abstract}

Keywords: Innovation. Tradition. Secularism. Centralization.

\section{"Caipiras" e "intelectuais"}

Ao avaliar as condições de vida nas diversas capitanias da Colônia Brasil no momento da chegada da Corte portuguesa à capital do Rio de Janeiro, o consagrado historiador e diplomata brasileiro Manoel de Oliveira Lima indicou terem os "viajantes alemães observado nos paulistas educados poder reflexivo e gênio inventivo", verificando-se na Capital “... gosto pelos estudos, mesmo abstratos, sendo cultivada a filosofia e conhecidas, posto que por meio de resumos defeituosos, as obras de Kant” (LIMA,1945, p.153). Nesse sentido, ter-se-ia diferenciado São Paulo das outras regiões coloniais. A valorização cultural dessa capitania contrasta com a apreciação geral sobre suas condições de vida, consideradas muito mais rústicas comparativamente a outras regiões do polo sudeste da Colônia e, que se dirá, às do então Norte, de colonização mais antiga. Tal rusticidade pode ser apreendida em diversas dimensões: na predominância das atividades agropecuárias, em detrimento de uma economia urbana; na simplicidade de costumes - verificada 
nas habitações, no mobiliário, nos trajes, nas rotinas de vida - que favoreceria, sobretudo, os ritmos de vida diurnos, em detrimentos dos noturnos. Tradicionalmente, contrastavam-se os costumes dos paulistas em relação ao dos habitantes do Rio de Janeiro, sendo aqueles muitas vezes ridicularizados como "caipiras". Semelhante condição - muito enfatizada em descrições escritas ou iconográficas posteriores à vinda da Corte - foi também claramente observada por Sérgio Buarque de Holanda, como um elemento que diferenciou e tipificou o vestuário dos paulistas por toda a primeira metade do século XIX (HOLANDA, 1977, p. XIII). ${ }^{1}$

Importante notar que, para Oliveira Lima, a simplicidade dos lares paulistas, observada no alvorecer do século XIX, denotava o isolamento, "a escassez do intercurso europeu", o que inevitavelmente instiga à reflexão: como ter-se-iam coadunado, se verídicas as observações reproduzidas, as dimensões do ser simultaneamente "caipira" - rural, isolado, frugal - e "intelectual" - estudioso, reflexivo, com acesso às leituras estrangeiras? Interpretações a esse respeito foram parcialmente apontadas por esse mesmo historiador. $\mathrm{Na}$ sua avaliação, se em São Paulo - cuja condensação urbana era comparável à de Minas Gerais - com o que se "deparava era na essência uma coletividade agrícola" (LIMA,1945,p.151), verificava-se muito dinamismo e racionalidade nessas atividades.

No plano urbano, embora apenas São Paulo e Santos, "os velhos pontos de desembarque e colonização", fossem comparáveis em importância às "principais vilas" da capitania mineira, "as aglomerações humanas surgiam mais frequentes...”, e, em que pesasse “... uma sensação de sociedade primitiva ou rudimentar..." , “testemunhavam uma geral prosperidade." Por sua vez,

[...] os distritos rurais, quer os de montanhas, quer os de planície, davam uma impressão de colonização intencional, denunciando diligência e um resultado positivo colhido da cultura dos cereais, do açúcar e do café e da criação de gado vacum, cavalar e sobretudo muar ... Os campos em si ... eram fertilíssimos e sugeriam riqueza, uma riqueza menos luxuriante do que a equatorial, porem mais segura e saudável na sua pompa mais discreta (LIMA,1945,p.152).

Dessa maneira, a maior intelectualização dos paulistas se explicaria pela sua própria frugalidade. Em contraste, nos centros mais importantes, "muito mais do que o gosto das artes, ciências e indústrias, fez o contacto com o europeu desenvolver-se no Reino ultramarino o gosto do conforto, do luxo e dos encantos da vida social" (LIMA,1945,p.129).

Se certa leitura das observações dos viajantes, elaboradas por Oliveira Lima, indica uma diferenciação cultural entre paulistas e habitantes de outras capitanias da Colônia, também pode-se 


\section{Marisa Saenz Leme}

pensar no modo como os primeiros teriam vivenciado o processo da Ilustração luso-brasileira, em suas sintonias e especificidades em relação ao que se desenvolveu em outras regiões coloniais. Muito sugestiva nesse sentido é a indicação da racionalidade agrícola acima apontada, que teria distinguido os paulistas às vésperas da chegada da corte portuguesa ao Brasil. Cabe salientar que, cerca de trinta anos antes, D. Luiz Antonio de Souza Botelho Mourão, o ilustrado Morgado de Mateus - primeiro governador geral de São Paulo após a recuperação administrativa da Capitania fizera observações negativas sobre os paulistas, semelhantes ao que os viajantes joaninos apontaram em relação às capitanias do então Norte do Brasil. Para ele, excetuando-se uma minoria de "fillhos do Reyno" e de "fidalgos Paulistas" - econômica e socialmente estabelecidos -, era lamentável o estado em que se encontrava a maioria dos paulistas: havendo entre eles "falta de Sociedade,... vivendo os homens fora de povoado, metidos pelos mattos sem ouvirem mais que a sua família, faltos de instrucção, e de doutrina...” (DOCUMENTOS Interessantes para a História e costumes de São Paulo - DI, VOL. XXIII, p.2). Avaliando que "a dispersão que se costuma habitar não permite a devida civilidade" (DI, XXIII, p. 253), considerava que o "atrazo da lavoura em S.Paulo" não se deve "senão a negligencia, e a preguiça dos Naturaes" (DI, XXIII, p. 374), em "terras... depravadas nos costumes", em que "a ociozidade he outro mal, e raiz de muita iniquiidade"...(DI, XXIII, p. 374), observando-se "uma preguiça que excede toda a explicação" ...(DI, LXXIII, p. 66). Simultaneamente, observava que "o luxo dos vestidos he desigual a possibilidade dessa gente"... o que se agravava pelo fato de serem "estrangeiras, não havendo ouro que as pague" (DI, XXIII, pp.377 - 381).

As assertivas do capitão-geral são problematizáveis, no sentido de estar ele procurando valorizar sua administração, pois se propunha a transformá-la, "aplicando-me a extirpar os vicios, e cultivar as virtudes” (DI, LXXIII, p. 66). Mas a diferença com as apreciações feitas sobre os paulistas, no início do século XIX, aponta também para os efeitos da vivência da Ilustração sobre a mentalidade e o ambiente cultural da Capitania na época. A situação descrita pelo Morgado seria fruto, sobretudo, de uma política econômica anterior: "na área rural de São Paulo, o processo de expansão do povoamento e de concentração da riqueza comercial havia impedido que a maior parte dos homens livres tivesse acesso a grandes parcelas de terras ou a um grande número de trabalhadores indígenas, tornando-os dependentes de roças de subsistência” (DERNTL, 2010, p. $65)$. 
Em estudo seminal, Maria Odila Leite da Silva DIAS (1968) descreveu e analisou a chamada Ilustração luso-brasileira, processo político-cultural que, iniciado com o governo pombalino, estendeu-se aos primórdios do século XIX. Congregando as elites metropolitanas e aquelas pertencentes à América Portuguesa num mesmo projeto de reforma socioeconômica, tinha ela o objetivo de reverter o que se avaliava como a decadência do Império. Centrada nos aspectos técnico-científicos e educacionais dos iluminismos, a Ilustração em Portugal teve suas bases político-filosóficas desenvolvidas a partir de fins do século XVII, acentuando-se na primeira metade do século XVIII (SILVA, 2006, pp.37 - 60), quando

\begin{abstract}
Os 'novatores' ou modernos fazem profissão de fé na ciência e no progresso, apregoam a necessidade de uma nova estética literária, multiplicam iniciativas que antecipam, com bons fundamentos, realizações futuras e que apontam para o desmantelamento progressivo da velha ordem cultural, mas não se desfazem de um dia para outro do peso das convenções herdadas. É portanto sob o signo da dualidade, da ilusão compartilhada e persuasiva da mentalidade barroca, com todo o seu arsenal de representações, que as Luzes irrompem, em Portugal, na primeira metade do século XVIII (ARAÚJO, 2003, p. 18).
\end{abstract}

Entre as suas dimensões de transformação sociocultural mais profunda e seus aspectos conservadores - em que se preservaram valores relativos às hierarquias sociais, às estruturas políticas e às concepções teológicas - a avaliação da Ilustração luso-brasileira é marcada por expressões como "paradoxo" e "ambiguidade" (SILVA, 2006). Nesse sentido, Maria de Lourdes Viana LYRA (1994) buscou uma interpretação global do "reformismo ilustrado" estabelecido pelo ministro português D. Rodrigo de Sousa Coutinho, a partir de 1798. Haver-se-ia configurado então, na visão da autora, uma "utopia do poderoso império", politicamente analisada como a incorporação das dimensões conservadoras das vertentes iluministas (pp.30ss) europeias. O que não teria, contudo, impedido o impacto das reformas no mundo luso-brasileiro.

As "limitações" da Ilustração portuguesa e, nesse sentido, também da espanhola (GUERRA, 1993, pp.55-79) - assim avaliadas tendo-se por parâmetro os aspectos mais radicais dos iluminismos francês e inglês - não excluem importantes questionamentos político-culturais e filosóficos ocorridos no cerne desses movimentos, a respeito da natureza do indivíduo e das relações entre sociedade e estado. Sobressai nos textos então elaborados a valorização do trabalho, da produtividade, das concepções utilitárias da vida e da felicidade e, de certo modo, também da liberdade. No que se refere às decorrências desse processo para o Brasil, diferentemente do que se passou na relação dos Bourbons espanhóis ilustrados com o mundo hispano-americano 


\section{Marisa Saenz Leme}

(RODRÍGUEZ, 1996, pp. 55-66), o estado português incentivou ao máximo a participação dos americanos na ilustração portuguesa, postulando a igualdade com seus pares metropolitanos. DIAS (1968) apresentou minuciosamente a integração técnico-científica da dimensão "brasileira" nessa relação, e LYRA (1993) evidenciou a importância da fundação, em 1796, do Seminário de Olinda, como difusor do conhecimento ilustrado e, em 1799, da Casa Literária Arco do Cego, ${ }^{2}$ que, em Lisboa, incumbia-se da "arregimentação dos ilustrados do Brasil na tarefa de pôr em execução, conjuntamente com os ilustrados do reino, a política de modernização do império português..." (p.83).

Expondo as diferentes origens e atuações regionais dos integrantes americanos da Ilustração luso-brasileira, esses estudos pioneiros visaram - como não poderia deixar de ser no contexto historiográfico em que surgiram - ao movimento como um todo. Dessa forma, adquiriram visibilidade nas análises as capitanias em que as atividades da Ilustração se desenvolveram com mais intensidade, quer quantitativamente quer no que se refere à proeminência dos seus membros: além da capital do Vice-reino, Minas Gerais e Pernambuco. Entretanto, pelas indicações contidas nesses trabalhos - somadas a outras referências historiográficas sobre São Paulo - evidencia-se a participação de segmentos paulistas no processo da Ilustração luso-brasileira, em seus aspectos econômicos. Mais difícil é a identificação das ações culturais, anteriormente à vinda de D. João VI, num ambiente colonial em que, no contexto das luzes, interpunham-se dimensões tradicionais e inovadoras. Mas por intermédio das obras dedicadas ao estudo de diferentes aspectos das manifestações artísticas e letradas da capitania de São Paulo, quer se trate da música, das artes plásticas, da arquitetura, da literatura ou da historiografia, é possível fazer uma primeira recomposição do que nesse plano se passou, a partir da chegada do Morgado de Mateus. Nesse sentido, embora poucos, há trabalhos preciosos. De um lado, o estudo seminal de Heloisa Belloto (1979) sobre a ação global dessa autoridade colonial ilustrada, embora com ênfase nos aspectos militar e econômico, também é de valor para a reconstituição da sua dimensão cultural. Mais recentemente, destacam-se os estudos de Amícar TORRÃO FILHO (2006 e 2007), sobre administração e espaço público na cidade de São Paulo no governo do Morgado, e o de Maria Fernanda DERNTL (2010), que aborda a evolução territorial e urbana da Capitania, desde a recuperação da sua autonomia administrativa em 1765 até o fim do governo de Franca e Horta, em 1811. Por sua vez, embora não diretamente voltado para São Paulo, o trabalho de Dionísio Machado 
Neto (2008) traz uma importante contribuição para o conhecimento da vida musical paulista na segunda metade do século XVIII.

Ao se enfatizar a importância da compreensão de ter ou não havido também na capitania de São Paulo uma vivência iluminista - necessária de ser dimensionada em suas especificidades - cabe naturalmente se aquilatar o seu limite no contexto de uma sociedade dominada pelas concepções mais antigas, teológicas, das relações entre o homem e a natureza, entre a sociedade e o estado.

\section{Um certo clima musical}

Conforme informou Vasco Mariz, “em 1790 já se dizia que na Sé de São Paulo se fazia música pouco inferior à dos maiores templos de Lisboa" (MARIZ, 1983, p. 36). Referia-se à obra de André da Silva Gomes, mestre-capelão vindo de Lisboa para a mencionada catedral em1774, que, no decorrer de sua longa vida, produziu cerca de 130 obras, em diversas modalidades de composições sacras, sendo suas missas e ofertórios considerados de grande beleza e complexidade. ${ }^{3}$

Como uma figura que acabou se tornando expoente no meio cultural e político da Capitania, desenvolvendo várias funções públicas (AMARAL, 1980, p.211; DUPRAT, 1995, pp. 57-75; MACAHDO NETO, 2010, p.87, p. 94), pode-se argumentar que o músico fora figura isolada, pois, em que pese a extensão e a qualidade da sua produção, quantitativamente São Paulo não se comparava a Minas Gerais, com sua "abundância de músicos e cantores” e, tampouco, a Recife ou Salvador (CASTAGNA, 2010, pp. 53ss). Contudo, a atividade do mestre-capela não ocorria em meio inóspito: pelo contrário, denota-se a existência de um ambiente a ela propício, com um público mais amplo, receptivo à produção musical. ${ }^{4}$

É para tanto indicativa a afirmação de que a chegada do lisboeta dera "estímulo à vida musical" (MARIZ, 1983, p. 36) paulistana. Observe-se que, desde a criação, em 1745, do bispado de São Paulo, faziam-se esforços no sentido de incentivar o desenvolvimento musical nos ofícios religiosos em diversos níveis hierárquicos: além da Igreja Matriz da Sé, o mesmo incentivo ocorria para as demais igrejas e irmandades da diocese. Atitude semelhante refletia-se nas festas religiosas promovidas pela Câmara, não só da cidade de São Paulo, mas também em vilas do interior. (MACHADO NETO, 2008; DUPRAT,1995; TRINDADE e CASTANHA,1996).

Ao contrário do que anteriormente se pensava, já existia um coro organizado na Sé quando da chegada de Silva Gomes; contudo, foi ele quem the imprimiu um novo e significativo impulso. Saliente-se que o cargo de mestre capela tinha "grande importância para o culto religioso e para a educação do povo", (AMARAL, 1980,p. 211) colocando-se às Sés a exigência de apresentarem a 


\section{Marisa Saenz Leme}

melhor música da cidade, com o fim de ressaltarem as festas da Catedral. O mestre de capela, compositor e regente, é a peça mestra deste sistema, pois trata e contrata serviços, recebe e paga executantes eleitos conforme suas conveniências artísticas e pecuniárias (ORBINO e DUPRAT, 1968, p.98).

Por sua vez, nas festividades promovidas pelas câmaras ou em recintos particulares, essas execuções eram grandemente assumidas pelo mestre-capela que, embora sem exclusividade legal, acabava atuando de modo bastante monopolizador em relação às atividades musicais, atitudes essas que constituíam fonte de tensão e protesto, dada a existência de outros músicos, excluídos do círculo por ele contratado (ORBINO e DUPRAT, 1968,, p. 99).

Em que pesem as assertivas historiográficas sobre exiguidade de recursos e improvisação (DUPRAT, 1995, pp.63 ss; CASTAGNA, 2010, p.66) - no sentido da inexistência de uma atividade profissional estruturada - o desempenho musical na Capitania implicava a presença de músicos instrumentistas; por sua vez, a organização e funcionamento de um coro significativo para a hierarquia social da época - como os das Sés - exigiam um esforço musical coletivo, além da inspiração individual de um artista. Um exemplo, em relação à Matriz da Sé: com a fundação do bispado, a função de organista havia se especializado, tornando-se tecnicamente independente da atuação do mestre-capela. Também, procurando elevar o nível "técnico e artístico" do coro, o $3^{\circ}$. Bispo de São Paulo, D. Manoel da Ressurreição - em cuja comitiva viera Silva Gomes para exercer o cargo precípuo - procedeu a um "levantamento de vozes, dentre os capelães da diocese" (DUPRAT, 1995, p. 63), reunindo os melhores padres-cantores para sua reconstituição.

A avaliação do que pode ter constituído o meio musical da capitania de São Paulo na época conta ainda com pouca bibliografia especializada, o que, supõe-se, deve-se em grande parte a juízos de valor que, na comparação com outros centros musicais, europeus ou da Colônia Brasil, toldam essas possibilidades. Procurando-se manter, porém, a dimensão histórica local, indica-se a existência, para o local na época, de um meio propício à atividade musical.

Dessa forma, assumindo a responsabilidade pela música das irmandades e das festas reais patrocinadas pelo Senado da Câmara de São Paulo, contava o novo mestre capela: "nos anos subseqüentes à sua chegada", "além de coro e órgão, com violinos, violoncelo, fagote, trompas e trompetes” (DUPRAT, 1995,p. 64). No início do século XIX, registram-se 14 músicos para a cidade de São Paulo e um para Cotia. É pouco? A comparação pode ser feita ao se avaliar que, no mesmo registro, foram computados quatro médicos, mais um em Santa Ifigênia (Idem,p. 58). 
Também é sintomático o fato de que, apesar da preferência que os bispos impunham às demais instâncias da Igreja e às autoridades civis para a contratação do mestre-capela da Sé, havia mais músicos a disputarem a responsabilidade pela organização musical de ofícios e festas religiosas variadas, patrocinadas quer pela igreja quer pelas autoridades laicas. Observam-se dessa maneira as consequências desse estanco: se, de um lado, servia ele para assegurar a manutenção em atividade permanente do mestre-capela, de outro inibia a possibilidade de expansão de outros artistas (ORBINO e DUPRAT, 1968).

No plano da difusão e treinamento musical, ao mestre-capela cabiam tarefas didáticas, como "manter escola pública para a Instrução musical da juventude". André da Silva Gomes foi particularmente dedicado a essa dimensão das suas funções, tendo obtido resultados multiplicadores, evidenciados pela existência de músicos e compositores que, atuando no século XIX, haviam sido seus discípulos (MACHADO NETO, 2008).

Em outro plano, elaborou ele, em torno de 1800, um tratado musical - A arte explicada de contraponto dividida por lições em três tomos - e, durante a existência da Colônia Brasil (compreendida neste caso até a sua efetiva extinção com a Independência), foram conhecidos nove títulos do que se poderia classificar como teoria musical, o primeiro deles datando de fins do século XVII. Embora em cinco deles, entre os quais no de André da Silva Gomes, não houvesse preocupação "com a citação de qualquer obra teórica" e os que o fizeram apresentassem " uma bibliografia muito pouco atualizada" (BINDER e CASTANHA, 1996, p.8), mesmo assim, na compreensão de Regis Duprat (2007), a produção desse gênero de obras mostra que "os músicos da época colonial exerciam a profissão de forma mais avançada do que poderíamos imaginar".

Esse mestre-compositor deu também início à constituição do arquivo musical hoje preservado pela Cúria Metropolitana da Sé de São Paulo (CASTANHA e GABRIEL, 2001, p.6), com a guarda, principalmente, das cópias de suas obras, mas também de cópias de compositores portugueses e italianos que se inseriam "no contexto atualizado da cultura musical européia da época" (DUPRAT, 1995, p.62).

Avaliando-se em conjunto o desempenho desse mestre-capela, observa-se o desenvolvimento nesse período de uma nova qualidade das atividades musicais, tanto no plano da sua organização social quanto no da composição artística. Evidencia-se um meio social que, apesar de geralmente tido como "acanhado", pode-se considerar propício à atividade musical. De acordo com Jaelson Britan Trindade e Paulo Castagna, "a cidade de São Paulo, sede do Bispado desde 1745, procurou instalar uma prática musical que simbolizasse a Igreja triunfante e o poder colonial, 
sobretudo no período de atuação, como mestre de capela da catedral, do compositor português André da Silva Gomes, desde 1774" (1996, p.13).

Reitere-se que esse compositor veio para São Paulo na comitiva do Bispo D. Manoel da Ressurreição, franciscano, intelectual de tendências iluministas. Conseguiu ele reabrir o Seminário, antes existente na cidade, que funcionou no Palácio Episcopal, visando aos estudos e debates teológicos e, em 1776, participou do primeiro censo realizado na capitania, entre autoridades civis e religiosas (TELAROLLI JR., 1993, pp.145-156).

Como já referido, tinha esse bispo o firme propósito de reordenar a estrutura de organização musical encontrada na sua diocese. Conforme o que muito bem expôs Machado Neto (2008), a sua atuação no contexto musical paulista da época inseriu-se num projeto cultural iluminista em articulação com o estado. Além das medidas expostas para a reconstituição do coro da Matriz da Sé de São Paulo, passou provisão de mestre-de-capela para diversas matrizes, incentivando, portanto, o desenvolvimento da musicalidade nas atividades religiosas das vilas do interior. Simultaneamente, teria ele instruído os vigários para que sempre impusessem os mestres-capela ao conjunto de execuções musicais nas atividades de cunho religioso que ocorressem nas suas esferas de administração eclesiástica.

Ou seja, difundir e centralizar foram faces de uma mesma moeda na atuação desse bispo ilustrado e, sob seu consciente impulso, obteve-se, por intermédio de André da Silva Gomes, a almejada "estabilização da atividade musical da Sé" (DUPRAT, 1995, pp.57ss).

No que diz respeito à expansão das atividades de composição, em suas conexões com as vilas do interior constata-se a existência de outros compositores coloniais paulistas no período em apreço. Já Mário de Andrade, na sua obra sobre o Padre Jesuíno do Monte Carmelo, registrara trabalhos nesse escopo na São Paulo de fins do século XVIII e início do XIX. O próprio biografado, que em Itu fora também organista das igrejas da Matriz e do Carmo, nas quais atuava principalmente como pintor, passou posteriormente de executante a compositor, sobretudo quando, já no período joanino, fundou a "congregação" dos Padres do Patrocínio: nas "pomposas festas inaugurais da igreja do Patrocínio, em 1820", com grande afluência de público, "até músicos da Capital se transportaram a Itu e aplaudiram as composições do grande padre"; entre eles, André da Silva Gomes (ANDRADE, 1963, p.251).

Regis Duprat, por seu turno, indicou ter encontrado, "mais de duas centenas "de obras concebidas entre os séculos XVII e XVIII, espalhando-se pelos arquivos de diversas cidades do 
Vale do Paraíba. Na sua avaliação, "esses depósitos comprovam acentuada comunicação entre músicos do passado nas diversas regiões do Centro-Sul brasileiro, pelo menos através da disseminação de cópias das obras musicais” (1995, p.13), difusão essa confirmada por Castagna (CASTAGNA, 2010, p.67).

Independentemente da qualidade musical dessas produções, conforme afirmou Mário de Andrade ao avaliar o valor estético da arquitetura e pintura coloniais de São Paulo, o que importa é a sua existência em si no que podem revelar da história sociocultural da capitania naqueles tempos.

Observe-se que o Morgado de Mateus, que também compôs uma música sacra, procurara, desde a sua chegada - anterior, portanto, à vinda do bispo D. Manoel da Ressurreição para São Paulo - a renovação da música que se executava na Matriz da Sé, incentivando ou impondo o que considerava moderno e de bom gosto; para tanto trouxe da Bahia o músico Antonio Manso, que por um ano foi mestre-capela da Catedral (BELLOTO, 1979, p.315). Com a vinda do bispo, desenvolveu-se acirrada disputa pelo poder no campo ilustrado, entre as autoridades máximas, religiosa e laica, de São Paulo. Nesse contexto, a composição do Morgado foi proibida de ser cantada nas festas eclesiásticas da Capitania (BELLOTO, 1979, p. 317).

Em relação aos estilos observáveis na vida musical sacra da Capitania de São Paulo, diferenciando-se do que até então predominara, verifica-se na obra de André da Silva Gomes interpenetração entre elementos barrocos e clássicos, mostrando-se, na avaliação das peças, a crescente influência do classicismo musical europeu. Como analisou Regis Duprat, a maioria dos movimentos de uma de suas obras-primas, a "Missa a cinco vozes", constitui uma estrutura clássica:

Se considerarmos a tonalidade de Si-bemol como a tônica da obra, o autor distribui os movimentos em todos os graus da escala, sempre em tons maiores, exceto no IV grau, o da Subdominante, que não é abordado, contrariamente às expectativas para com um autor com forte influência barroca. Diríamos que o autor pratica aqui uma espécie de renúncia consciente a essa influência; renúncia às subdominantes e às tonalidades menores. Opta por um esquema de tons maiores conferindo à peça um pathos glorioso...a fórmula cadencial escolhida pelo autor... indica uma evolução para a aceitação dos padrões clássicos em substituição aos barrocos (CD/1995, pp. 2-3).

Por sua vez, embora grandemente centrada em torno da Igreja, a ambiência musical da época em São Paulo também adquiria expressão propriamente laica. Mariz (MARIZ, 1983, p.36) registrou que em 1770 - alguns anos antes, portanto, da chegada de Silva Gomes - cantava-se em 
São Paulo uma ópera de Caldara, compositor veneziano morto em 1736, um dos grandes últimos do barroco, admirado por clássicos como Haydin, Mozart e Beethoven.

Observe-se que, embora sem a visibilidade da música sacra, a prática da música profana com ela coexistia já nos séculos XVII e XVIII, podendo ocorrer

[...] durante a encenação de pequenas "óperas", comédias e entremezes. De resto, a documentação tem mostrado que entre as populações dessas vilas paulistas do Seiscentos e Setecentos, era usual tanger viola, harpa, cítara e até pandeiro. Em meados do século XVII, circulam em Vilas como São Paulo e Santana do Parnaíba livros de canto de órgão, cartapácios e papéis de música, não apenas em mãos dos Mestres de Capela. E muitos daqueles tangedores de viola eram letrados: "tinham à mão um Cervantes, um Vieira, um Mendes Pinto, um Bento Pereira ou livros de comédias e entremezes, além de muita literatura 'espiritual', jurídica e médica" (TRINDADE, 1984, p.18).

Também o Morgado de Mateus estimulou as apresentações do canto lírico. A sua "primeira ação" nesse sentido foi "montar uma estrutura física e humana para a ópera paulistana... Para tanto, e já demonstrando a organicidade do espaço, anexou a casa de ópera ao seu palácio de governo. Ao que tudo indica foi em 1767 que se iniciou a construção" (MACHADO NETO, p.310), logo no início, portanto, do seu governo. Posteriormente, procurou organizar oficialmente a apresentação dos espetáculos. Para tanto, nomeou um diretor para "o divertimento das operas", com justificativas exemplares para a compreensão do sentido de disciplinaridade da época. Considerando que "o divertimento das operas", uma prática verificada "em a mayor parte das Capitanias deste Brazil, nem pode continuar, nem subsisitr, sem haver Director, que dê providencias ás innumeraveis faltas que de continuo sobrevem aos que entram neste exercicio..." atribuía-se ao diretor designado a faculdade de

[...] obviar todas as faltas e fazer aprontar nos dias determinados as Operas estabelecidas, ordenando nesta materia o que the parecer mais conveniente, para o que os Muzicos, e todos os Atores das ditas Operas cumpram as suas ordens, e elle os poderá mandar prender e a mesma ordem todas as vezes que for necessário e catiga-los...” (DI, VOL. XXXIII, p.79)

Cabe salientar que, simultaneamente à disciplinaridade imposta à apresentação das "Operas", o Morgado procurava impor um padrão moral à dimensão popular dos festejos religiosos, 
como se apreende das instruções militares emanadas em fins de 1772, por ocasião da próxima festa de S. Gonçalo, a se realizar em Santos, informado o Morgado que nesses festejos

[...] se pertendem fazer algûas danças menos decentes ao mesmo Santo trazendo em chusmas de noite e de dia pelas ruas entre homens e mulheres, de que podem seguir-se acções indecorozas, que nam devem praticar-se nem consentir-se entre Catholicos...", ordenava que somente se permitissem "barulhos... licitos ao publico, e mascaras para honra e Louvor do mesmo santo... com aquelle socego, decência e seriedade que deve haver em semelhantes festividades" (DI, VOL. XXXIII, p.83).

\section{Arquitetura e artes plásticas: religião e modemidade}

No período em apreço, foram significativas as realizações nos campos da arquitetura e das artes plásticas, em grande parte relacionadas às dimensões religiosas, mas também, no caso da primeira, estendendo-se progressivamente para as construções oficiais e particulares.

Ainda que lentamente, a arquitetura acabou sofrendo a influência das novas concepções urbanísticas introduzidas a partir do governo do Morgado de Mateus, em que se destacou a firme orientação no sentido da fundação de novas vilas (BELLOTTO, 1979, pp. 171-201), objetivando-se desenvolver um povoamento economicamente diversificado, processo esse que, na prática, redundou de uma interação entre autoridades régias e população local (DERNTL, 2010). Nesse contexto, as transformações propriamente arquitetônicas se farão sentir de modo claro nos finais do século XVIII, quando

[...] a cidade de São Paulo parece emergir como espaço privilegiado no campo da arquitetura e urbanização... Não só as construções oficiais mas também as casas comuns passaram por transformações quanto à escala, sistema construtivo e elementos da arquitetura...Nas práticas urbanísticas adotadas pela edilidade paulista, uma perspectiva sistemática de cuidado técnico foi suplantando o anterior trato casual e profilático dos espaços urbanos... (DERNTL, 2010, p.p. 140-141).

$\mathrm{Na}$ virada do século XVIII para o XIX, essas inovações "puderam contar com um quadro renovado de técnicos" (DERNTL, p. 141). Contudo, é bastante significativo para a compreensão do ambiente cultural em torno da arquitetura, no último terço do século XVIII, o desempenho, nesse campo, do franciscano Frei Antonio de Sant’Ana Galvão que, de modo improvisado, renovou a arquitetura religiosa da cidade de São Paulo. 


\section{Marisa Saenz Leme}

Filho de rica familia de Guaratinguetá, nascido provavelmente em 1739, ${ }^{5}$ Frei Galvão, "que no século chamava-se Antonio Galvão de França" (FONDA, 1972, p.73), destacou-se por suas realizações arquitetônicas, com atuação inovadora materializada em construções religiosas. Para tanto contou, inicialmente, com o incentivo do Morgado de Mateus. Construiu a Igreja e o convento da Luz e participou como assistente da construção da Capela de São Francisco, para a qual deu a solução arquitetônica final. Cabe salientar que a conclusão das obras se deu posteriormente à saída do Morgado da Capitania de São Paulo. A Capela da Ordem Terceira de São Francisco foi concluída em 1785, a igreja da Luz, inaugurada em 1788 e o Convento, em 1802 (FONDA, pp. 73ss; TOLEDO, 2001, pp.38-9).

O valor do trabalho arquitetônico de Frei Galvão é grandemente reconhecido pelos especialistas dessa área. Afastando-se do modelo jesuítico, foi ele responsável pela introdução em São Paulo da "igreja com planta poligonal", da qual foram "raros os exemplos na arquitetura brasileira", o que o identifica como "um arquiteto paulista muito original". Um "arquiteto de mérito", pois ainda o convento da Luz por ele projetado "é bem arejado e saudável, com corredores desafogados e abertura para pátios ajardinados... com acomodações até hoje bem ajustadas ao programa" (TOLEDO, 2001, pp.40-41).

De que forma se tornou Frei Galvão arquiteto e construtor, acumulando à "direção espiritual" do recolhimento da Luz, à qual fora elevado, a concretização material deste? Como salienta Benedito Lima de Toledo (2001, p.39), a formação do religioso, que se dera em conventos da Bahia e do Rio de Janeiro, "permitiu-lhe travar conhecimento com a arte brasileira..." do atual Nordeste e da capital do vice-reino. Por sua vez, sua provável participação na construção da Capela de São Francisco teria, na prática, "formado um importante arquiteto do século XVIII em São Paulo“. Observe-se que essas inovações arquitetônicas inseriam-se num contexto urbanístico em que se procurava ampliar o espaço público. O Recolhimento da Luz foi "obra considerada pela Câmara de utilidade pública, pois, para além da devoção das recolhidas, constituiria um passeio à população, servindo 'de ornato de recreação e ocasião de devoção às pessoas que ali concorrem todos os dias especialmente aos sábados'” (TORRÃO FILHO, 2006,p.164).

Quanto ao campo das artes plásticas, permaneceu ele voltado para a produção de cunho religioso. Individualmente, destaca-se nesse sentido a figura de Frei Jesuíno do Monte Carmelo, nascido Jesuíno Francisco de Paula Gusmão. Bastante diferente de Frei Galvão foi o sentido da sua vida e obra. De familia pobre, mulato, "sem pai” (ANDRADE, 1963, p.31) nasceu em 25 de março 
de 1764, em Santos, onde, na adolescência, dedicou-se às artes plásticas, tendo executado algumas obras de pintura e de torêutica religiosa. Com 17 anos foi para Itu, onde se destacou pelas pinturas realizadas na decoração das igrejas do Carmo e da Matriz. Mostrando sua versatilidade e o ambiente polivalente da época, foi também organista das referidas igrejas (Idem, pp.32ss; AMARAL, 1980,p. $315 s)$.

Jesuíno Francisco somente se ordenou padre com 33 anos, quando, com o "intuito de estudar" mudou-se para São Paulo, onde continuou realizando pinturas para instituições religiosas (AMARAL, 1980, p.315). Artisticamente, sobressaiu principalmente como pintor, sendo bem avaliado quanto ao valor estético do seu trabalho. Mário de Andrade (1963, p.194) o considerou "a mais curiosa e importante figura da arte colonial paulista". Embora genericamente relacionada ao barroco, sua obra - como grande parte dos trabalhos artísticos da Colônia Brasil - marca-se pela incorporação criativa dos elementos locais, distanciando-se de concepções estéticas ortodoxas:

Arroubado, se deixando levar pelos instintos e formas da vida, o padre Jesuíno do Monte Carmelo deixou uma obra singularmente "romântica" confessional. Porventura a obra mais típica do marginalismo mulato e do individualismo, da nossa arte colonial já estudada. Este romantismo confessional, que só era romântico por não determinar uma estética, é que mais caracteriza a obra do pintor paulista...(ANDRADE, 1963, p.195).

Assim como no que se refere ao campo musical, Jesuíno do Monte Carmelo não era uma exceção isolada do meio. Pelo contrário, outros pintores atuavam e se distinguiam na Capitania, parcialmente distribuindo-se em funções especializadas, como as de "pintores-douradores e pinceladores", o que pode ser um indício da existência de oficinas de pintura e escultura em São Paulo, como ocorria em outros centros artísticos do Brasil-Colônia. Mas trata-se de assunto ainda muito difícil de determinar, dada a carência de estudos sobre a temática (TIPARELLI e SALOMÃO, 2001, p.92).

Dentre os artistas então atuantes de que se tem conhecimento, o mais referido é José Patrício da Silva Manso. Também provavelmente santista, trabalhou ele em Itu com o Padre Jesuíno, sendo em parte considerado seu mestre. Os pintores atuaram juntos na matriz de Itu, onde os quadros seriam "de ambos"; em São Paulo, realizou Silva Manso pinturas na Igreja de São Francisco, em que, como referido, também atuou Frei Galvão (ANDRADE, 1963, pp.: 119;158;259-262). 


\section{Marisa Saenz Leme}

A visibilidade adquirida pelo Padre Jesuíno ${ }^{6}$, em face da existência de outros artistas em atividade na Capitania, seus coetâneos, traz dificuldades para a identificação da autoria das pinturas então realizadas. Lembrou Mário de Andrade que existem

[...] ainda...principalmente por Itu, Porto Feliz e Sorocaba, mais alguns quadros que a gente se vê tentado a lhe (Monte Carmelo) atribuir. Mas sempre é bom não esquecer que viveram ou passaram por Itu, mais ou menos contemporâneos de Jesuíno, alguns outros pintores, e ter cuidado com os exageros do amor..." (1963, p.86)

Mais tarde, no século XIX, vindo da região de Itu e nascido em 1810, sobressaiu na pintura aquele que ficou conhecido como Miguelzinho Dutra. Por sua vez, na região de Mogi das Cruzes, no virar do século, atuavam outros pintores, como Manoel do Sacramento e Antonio dos Santos (TIPARELI e SALOMÃO, 2001, pp. 110ss).

A reconstituição das realizações verificadas na Capitania de São Paulo nos campos das artes plásticas e da arquitetura, na segunda metade do século XVIII e início do século XIX, indica a possibilidade de ter nela se configurado, embora não com a mesma intensidade observada no campo musical, um entorno que favorecia a expansão da pintura, bem como a inovação arquitetônica, grandemente improvisada, com sentido então moderno.

Mas o fato historiográfico é que ainda há um mundo de pesquisa a se percorrer para um melhor conhecimento desse passado artístico:

O conceito de simplicidade das artes em São Paulo... vem sendo revisto...Considerado por alguns historiadores uma 'linguagem popular e ingênua', chegando a ser chamado de 'barroco sertanista', o período colonial paulista caracteriza-se por uma distinção em relação às demais regiões brasileiras... Pesquisas recentes têm dado conta da importância da imaginária e das técnicas construtivas no período colonial paulista...(TIPARELI e SALOMÃO, 2001, p.90).

\section{Fragilidade literária, força historiográfica}

Conforme a apreciação de autores que estudaram as dimensões da cultura erudita letrada, passíveis de se observar em São Paulo na segunda metade do século XVIII, "as letras compareciam de maneira oficial, em sentido puramente comemorativo, como verso e prosa de circunstância, nas solenidades públicas" (CÂNDIDO, 1967, p.164), "mal escondendo o propósito de bajular o delegado real na capitania" (PINHEIRO, 1975, p.135). Ainda que nessa conformação, para ambos 
os autores a valorização das atividades nesse campo desenvolvidas é fundamental para o conhecimento cultural da sociedade que as produzia.

Um primeiro acontecimento no sentido assim expresso, no período em apreço, foi a fundação da "Academia dos Felizes" - uma "manifestação de literatura associativa ocasional"” em meio à realização das festas promovidas em homenagem a Sant'Anna, santa de devoção do Morgado de Mateus, em agosto de 1770. Tratou-se de uma festa "monumental" (TORRÃO FILHO, 2007, P. 230), de acordo com os padrões da época, durando ao todo nove dias, em que se comemoraram simultaneamente diversos acontecimentos, religiosos e laicos. Nesse último campo, incluíram-se desde natalícios reais ao encontro, durante a administração do Morgado, das minas de Tibagi, no atual Paraná.

A festa inaugurou-se na noite do dia 16 de agosto, "aparecendo pelas ruas um cartel, que se compunha da Fabula de Tirezias, conduzido em hum Carro de Triunfo com muitas Luzes, a que precederão outros muitos carros igualmente muito iluminados, com muitas mascaras, bailes e instrumentos Muzicos de toda qualidade..." e, no segundo dia, "houve folias de pretos pelas ruas, representadas pelos Estudantes dos Cursos de Filosofia e Theologia..." (RELAÇÃO das festas públicas que na cidade de São Paulo fez o Ilustríssimo e Excelentíssimo senhor dom Luiz Antonio de Souza Botelho Mourão, Governador e Capitão General dada. Capitania,1770, folha 4). ${ }^{8}$ Seguiram-se as apresentações religiosas, com iluminação da catedral, fogos de artifício, missa e procissão realizada no domingo, de que participaram todas as Irmandades... todos os Religiozos, dos trez Conventos..., tendo ficado "o Santíssimo exposto por todo o dia, com muita profuzão de Cera...Para as comemorações, "se repartio a Muzica da Sé, e da Opera, com todos os Muzicos que se acharam mais especiaes, nas Terras da Capitania, e das Vizinhas de Minas Geraes...” (p. 4 a). O evento encerrou-se no domingo, dia 26, com a apresentação, à tarde, dos "Cavalleiros de Paranahiba" e, à noite, de "Opera publica” (RELAÇÃO das festas..., p. 10 a).

No contexto de um acontecimento de grande impacto para os diversos segmentos que compunham a população da colônia, as manifestações literárias apresentadas na Academia dos Felizes resultaram na sua maior parte de encomendas feitas pelo Morgado, destacando-se nesse sentido os clérigos, entre professores ou outros segmentos que poderiam se constituir na intelectualidade da época. Foram sete horas de sessão, das dezenove às duas da madrugada, em que se recitaram ao todo 136 peças, "sessenta e oito em português, cinquenta e nove em latim, seis em espanhol, uma em francês, uma em italiano" e, o que é importante frisar, embora comparecendo 


\section{Marisa Saenz Leme}

com apenas uma recitação, houve também um registro "em língua de caboclo", ou seja, o tupi (FONDA, 1972, p.68).

A sessão inaugurou-se com uma oração do Presidente da Academia, o juiz de fora da Vila de Santos José Gomes Pinto de Moraes, em que muito se louvou o Morgado, como, aliás, ocorreria nas outras apresentações - orações, sonetos, poemas - desse evento literário. No seu discurso, invocou o juiz a "Feliz Capitania, que diversa te ves agora, si te comparas com o que foste em outros Governos! Fostes sempre nobre, mas nunca tão culta, sempre valorosa, mas hoje mais disciplinada. Teus Portos hoje se respeitão com novas Fortalezas, os teos Certões se enobrecem com Villas ..." (RELAÇÃO das festas... p. 34a). Em seguida à fala do Presidente, ocorreu uma disputa entre dois oradores, um franciscano e outro carmelita, a respeito do "problema" de se saber "de onde resultava mayor gloria a S. Exa., se de ser Morgado de Matheus, se de ser General desta Capitania de Sam Paulo" (RELAÇÃO das festas... pp. 36a -39b). Na oportunidade, o próprio governador declamou soneto de sua composição, "Em louvor da Gloriosa Santa Ana", logo no início da sessão. Apresentaram-se ao todo vinte membros, dos quais, incluindo o Morgado, apenas sete eram leigos. Praticamente a totalidade das composições dos religiosos se deu em latim.

Nos sonetos de inspiração religiosa, destacou-se Frei Galvão, também devoto da santa homenageada, com dezesseis composições. Não se constata, contudo, nessa produção literária a criatividade revelada pelo franciscano na arquitetura. Na avaliação de Fonda (1972, pp.83-4), "sua poesia é... um daqueles exercícios tão em voga entre os alunos da Companhia de Jesus, obrigados a compor circunstancialmente por uma tradição que remonta aos ditames da "Ratio Studiorum", que os quer exímios latinistas... Preso mais à forma do que propriamente à inspiração, parece-nos antes um esfoçado metrificador, o mais das vezes bem sucedido, mas sem a graça natural de um poeta nato, capaz de suscitar no leitor qualquer sentimento de admiração... Contudo, não se pode... negarlhe a presença de um sentimento religioso", e, frise-se: na análise desse autor, também "patriótico".

Embora avaliada como de qualidade estética muito ruim a poesia apresentada na sessão da Academia, valoriza-se a iniciativa pelo seu objetivo de congregar a produção então passível de ser realizada (PINHEIRO 1975, pp.134-5). Fora a primeira vez que na Capitania ocorrera atividade de semelhante teor, já manifestada no Rio de Janeiro e na Bahia. É de ressaltar ainda o zelo ilustrado do Morgado: fez copiar, "em letra de consumado calígrafo", e organizar em "códice de bela encadernação", "adornado de belas capitulares e interessantes vinhetas", tudo o que foi apresentado naquele momento (RELAÇÃO das festas... pp. 1 a 5). 
Em que pese o estímulo que o Morgado de Mateus procurou dar à produção literária, nem por isso houve avanços no sentido de uma apropriação mais ampla da literatura, como uma atividade que, aos moldes do Antigo Regime, pudesse, sob a forma do patronato, se organizar individual ou corporativamente e, dessa maneira, atingir valor socialmente considerado artístico, com difusão junto a determinado público. (CHARTIER, 1990, pp.121-139; 1994, pp. 33-65).

O próximo momento de um ato literário acadêmico, na Capitania de São Paulo, se deu vinte anos após a realização da "Academia dos Felizes", em homenagem ao então governador-geral de São Paulo, Bernardo José de Lorena, no “Faustíssimo dia dos anos Da Rainha Nossa Senhora, Em que se concluiu A importantíssima Obra do Senado E Nova Cadeia”( ACADEMIA em homenagem a Bernardo José de Lorena, frontispício), obras essas efetivamente resultantes da ação do governador:

Inovações mais expressivas na fisionomia urbana parecem ter se dado sob o governo de Bernardo de Lorena (1788-1797), quando se deu início à construção do Quartel de Voluntários Reais, da nova Casa de Câmara e Cadeia, além de se terem feito as obras de um chafariz do largo da Misericórdia e de uma ponte sobre o Anhangabaú (DERNTL, pp.140-141).

Tratou-se de uma sessão organizada pelo Senado da Câmara da cidade de São Paulo, em que se apresentaram cinco oradores, com vários trabalhos cada. Ademais da "Oração Acadêmica... que recitou na Sala maior do Senado da Câmara o Juiz Presidente dela", apresentaram-se com poemas e sonetos: Salvador Nardi de Vasconcelos Noronha, camarista posteriormente agraciado com o título de cavaleiro de uma das ordens militares do Reino (SILVA, 2005 p.210); Frei Francisco de São Carlos, franciscano nascido e ordenado no Rio de Janeiro, que na época ministrava curso de Teologia Dogmática no seminário diocesano de São Paulo, tornando-se depois orador famoso (DOMÍNIO PÚBLICO, 2011); José Arouche de Toledo Rendon, na época "capitão agregado ao $1^{\circ}$. Regimento de infantaria de milícias" (AMARAL, p. 383), e que posteriormente desempenhará importantes papéis na política paulista.

Por sua vez, José Vaz de Carvalho e Frei Francisco alternaram-se com orações em louvor ao governador, sendo curioso o enunciado apresentado pelo último, que discutia de onde resultaria "mais gloria? Se como Aluno de Marte, ou se como de Minerva, Constituindo Herói pelas Armas, ou graduado nas Letras" (ACADEMIA em homenagem a Bernardo José de Lorena, p.76). A sessão foi divida em três "assuntos acadêmicos", assim distribuídos: $1^{\circ}$.) "Sua paixão pelo bem público, demonstrada em tantas obras úteis, Magníficas Em um Governo Suave; 2 ${ }^{\text {. }}$ ) "Seus cuidados 


\section{Marisa Saenz Leme}

militares pela pública segurança, Provados na destreza das nossas Armas, Exercitada, Pelo exemplo do seu Comando"; $3^{\circ}$.) "Sua Fidalguia Pessoal Hereditária, Origem De toda a presente felicidade" (ACADEMIA..,p. 84).

Cerca de vinte anos mais tarde, quando da vinda da Corte portuguesa para Rio de Janeiro, o então Governador Geral de São Paulo, Franca e Horta, ordenou a realização, à moda da época, de um conjunto de festas, dada "a noticia da feliz chegada... Devendo todas as classes do Povo concorrerem para mostrar a alegria publica” pelo acontecimento. Ordenou então que, depois dos três dias de "Eluminação... desta Cidade, e dos Actos de Religião... se fação os profanos festejos publicos... entre os quais são os de quatro tardes de Cavalhadas, e outras tantas de Touros, e que em cada húa dellas hajão Carros de Danças feitos a custa das Artes e Officios Mecânicos...” (DI, VOL. LVII, pp. . 253-256). Nesse contexto, demandou em oficio aos "Professores de Philozofia, Retorica e Gramatica", que,

No detalhe das Festas, que se vão apromptar para festejarmos a feliz chegada de S.A.R...está determinado, que nas três noites de Encamizadas, que hão de fazer os Cavlleiros Milicanos e nas três noites de fogos dados pelo Corpo do Negocio, os Estudantes de Todas as Classes darão hum Carro de Parnazo com Oitero em que se repitão, e facão obras aluzivas a tão sublime assumpto: $\mathrm{O}$ que participo a V.Mces. não só para que assim o fação saber aos seus respectivos alunos, mas tão bem para os derigirem não só ....ao festejo mas tão bem nas mesmas Compuzições Poeticas afim de poderem ser todas aplaudidas pelo Povo. Não devo recomendar-lhes a Importância desta matéria, porque conto com as suas vontades, ainda mais amplas, que os meos dezejos (DI, VOL. LVII, p.255).

Independentemente de terem ou não essas festas sido executadas em toda a sua extensão - o que demandaria um estudo específico a respeito -, vale registrar o nível de importância atribuído às manifestações literárias pelo Governador. Se, de um lado, estavam elas subordinadas às exibições gerais, de outro se mostravam imprescindíveis, levando à intimação para que se produzissem, num meio estudantil, em que, presume-se, os outros elementos da festa exerciam atratividade bem maior.

A par das iniciativas de caráter oficial, registra-se, simultaneamente, o surgimento esporádico na Capitania de pasquins que atacavam o governo do Morgado de Mateus e, posteriormente, o de Franca e Horta. Em duas cartas, uma ao Vice-Rei do Brasil, Conde de Cunha, e outra para o então Conde de Oeiras, futuro marquês de Pombal, Don Luis Mourão registrou essas ocorrências, imputadas "ao espirito de opozição" ao seu governo, que observara na cidade de São Paulo e "em toda a Capitania". Oposição essa por ele atribuída a "Jesuitas ocultos que me parece 
que aqui há" e a "Republicanos acostumados a Governar a terra a seu modo", que não teriam aceitado suas medidas militares, com a criação de "Novas Tropas Auxiliares" (DI, VOL.XXIII, pp. 187-8). Dessa forma, no dia de "annos de S. Magestade", que o Morgado pretendia comemorar ao estilo da época, com missa cantada, jantar público e "exercício grande de fogo com a mayor parte das Tropas",

[...] foram pregar na porta (da Igreja) huma vergonhosa sátira em que atacavão, não os meus vícios como elles o merecem, mas as principaes dispozições do meu Governo em que executo as Reaes Ordens de S. Magestade; entre estas são escarnecidas as Tropas, e o seu luzido fardamento, chamando-me de destruhidor do Povo; as lavouras, chamando-me de "carreiro"; as Villas, chamando-me de Fidalgo de Aldeã, e de meya tigela", e outros impropérios indignos de pôr na prezença de V. Exa., concluindo com muita ameaça de darem de mim conta a V. Exa. para que me dê carreira, e me pozesse na forca". (DI, VOL.XXIII, pp. 188-9).

Por sua vez, no início do século XIX, chegou ao conhecimento de Franca e Horta a informação de "haverem-se afixado... alguns Pasquins" em Cananéia, sem que fosse tomada qualquer providência punitiva por parte do Juiz Ordinário da Vila. Em decorrência, advertia o governador:

[...] olhe para o que a Ley em semelhante cazo determina, porque assim saberá o que devia fazer pôr desempenho do seu Cargo, attentas as conseqüências que se seguem se deixar impune tal delito...Tome na mais seria concideração os deveres a que está Ligado, se quer poupar me o disgosto de o advertir, e prehencher as obrigaçoens do meu lugar (DI, VOL XVI, p.69).

A existência desses pasquins foi avaliada por Antônio Cândido como "manifestação literária", constituída por "verrinas contra o governo" (1967, p. 165) de "cunho popular" (1975, p.79). O que não se sustenta, quer pelo confronto documental, quer pela compreensão teórica do "popular" e da produção considerada sátira, no período estudado. O conteúdo político das manifestações assim compreendidas, já de difícil apreensão, torna-se ainda mais complexo de ser avaliado, em decorrência da própria polissemia do termo "povo" (CHARTIER 1990, pp.189 a 213). Sob o manto do popular, observa-se que as produções de caráter satírico constituíam-se grandemente em disputas entre camadas de elite em face dos desmandos do Antigo Regime, tratando-se de reações circunstanciais às autoridades instituídas, sem se objetivar nem a organização sociopolítica como um todo, nem a dimensão popular dessas vivências. ${ }^{9}$ Entendimento esse que se verifica como particularmente adequado para o caso em apreço. 
Diferentemente da literatura, na historiografia - mantendo-se os limites já apontados para a Ilustração no Brasil - observam-se, por intermédio dos trabalhos realizados pelos paulistas Gaspar Teixeira de Azevedo - ordenado beneditino como Frei Gaspar da Madre Deus - e Pedro Taques de Almeida Paes Leme, posturas intelectualmente inovadoras para a época. Primos, amigos e em relação de intercâmbio cultural, nasceram eles praticamente ao mesmo tempo, na segunda década do século XVIII, o primeiro em Santos e o segundo na Capital paulista.

Após ordenar-se monge beneditino, em 1738, na Bahia, viajando em seguida para Portugal, Frei Gaspar da Madre Deus passou, por opção, boa parte da sua vida ativa como prelado no Rio de Janeiro, onde se encontrava desde 1743. Recusou-se, para tanto, a aceitar sua indicação como "Abade de São Paulo", posto de alta graduação na hierarquia beneditina, para o qual, em 1752, fora eleito pelo capítulo geral de sua ordem. De acordo com Taunay, essa atitude teria decorrido do seu impulso de pesquisador, pois, "já nesta época era o revolvedor incansável de cartórios e arquivos" (TAUNAY, 1975, p.10). Mas, como ao menos parte dos documentos que precisava encontravam-se em São Paulo, indica-se também que a sua permanência no Rio de Janeiro se deveu, sobretudo, ao clima intelectual, à sociabilidade intelectual e política possível de ser vivenciada nessa cidade, prestes a se tornar capital do Vice-Reino. Observe-se que o Rio de Janeiro constituía uma das três localidades da América Portuguesa, junto com Bahia e Pernambuco, articuladas com a Academia Real de História, fundada em Lisboa, em1720, e responsável, ainda que sob as limitações da época, pela renovação dos métodos de lidar intelectualmente com a avaliação do passado (CUNHA, 2001, pp.11-47).

Em 1759, Frei Gaspar foi eleito membro supranumerário - ou seja, que reside fora do local da sede - da recém-surgida, em Salvador, Academia Brasílica dos Renascidos, "com a incumbência de escrever as memórias do Bispado de São Paulo" (Idem, 2006, p.74). Alegando a distância em que se encontrava dos arquivos necessários de se consultar, propôs a inclusão de Pedro Taques na realização da tarefa, indicando-o para ser incluído como membro supranumerário da Academia (Idem, 2004, p.146).

Os "Renascidos" objetivavam a publicação de obras "de bastante vulto... abrangendo questões de história, geografia, etnografia, zoologia e botânica do Brasil', além de inclúrem a literatura. De acordo com Antonio Cândido, "pela primeira vez bruxuleou uma vaga consciência de integração intelectual no Brasil', pois na academia procurou-se congregar como membros "supranumerários os letrados de outras partes da Colônia" (1975, p.80), tendo os "Renascidos", 
como mostrou Iris Kantor, o projeto de elaborar, de modo corporativo, uma história da América Portuguesa.

Embora o projeto dessa Academia não tenha vingado - dado seu fechamento um ano após sua fundação - parte dos seus membros elaborou, posteriormente, obras individuais no teor das concepções historiográficas nesse momento visualizadas; por sua vez, a iniciativa também proporcionou relativa integração entre o que constituía a intelectualidade na época. Por esse caminho, Frei Gaspar entrou em correspondência com o poeta Cláudio Manoel da Costa, com quem, por sua vez, Pedro Taques já estava em contacto (CÂNDIDO, 1975, p.80).

No que se refere a sua carreira prelacial, dez anos após recusar o cargo de Abade de São Paulo, Frei Gaspar assumiu o de Abade do Rio de Janeiro e, em 1765, foi nomeado para o mais alto posto da ordem dos Beneditinos, no Brasil, o de Abade Provincial. Tornou-se assim responsável por todas as instituições que a Ordem possuía no Brasil, obrigando-o a visitá-las e, portanto, a viajar por vários pontos da Colônia, de Santos à Paraîba do Norte. Quatro anos após, contudo, com 50 anos de idade, afastou-se do cargo e recolheu-se ao mosteiro beneditino de Santos, onde se fixou, tendo permanecido fora apenas quatro anos, entre 1780 e 1784, quando voltou ao Rio de Janeiro para assumir o cargo de mestre dos noviços. Faleceu em 1800 (TAUNAY, 1975, pp. 7-26).

Foi fundamentalmente no período da sua vida passado em Santos que se dedicou aos escritos históricos, podendo empregar a documentação até então recolhida. Alguns anos depois da volta à sua vila natal, a partir de 1774 até 1798, foi "eleito e reeleito continuamente cronista-mor" da Ordem dos Beneditinos no Brasil, tendo ainda exercido a função de Comissário Geral Visitador da ordem na Capitania, o que lhe permitiu viajar e completar sua documentação para a história desta. Elaborou nesses anos o "histórico das ocorrências principais da Província" e, em 1786, concluiu aquele que, dos seus estudos conhecidos, ${ }^{10}$ adquiriu maior importância, as "Memórias para a história da capitania de São Vicente, hoje chamada de São Paulo, do estado do Brazil'. Fazendo parte dos manuscritos elaborados pelo beneditino, no decorrer de sua longa vida, sempre em interlocução com o primo Pedro Taques - foram publicados, em dois tomos, em Lisboa, em 1797, pela Academia Real de Ciências (TAUNAY, 1975, pp.18-20).

No que se refere a Pedro Taques, considerado por Affonso de E.Taunay (s/d/p) o mais importante autor da Colônia Brasil e, por Barreto do Amaral, "um dos maiores genealogistas da história de São Paulo" (1980, p.451), sua existência foi muito atribulada. Nascido em família tradicional e abastada, tendo ocupado diversos cargos na burocracia colonial, acabou morrendo na pobreza, em 1777, aos 63 anos de idade. 


\section{Marisa Saenz Leme}

Iniciando no Brasil a sua "Nobiliarchia Paulistana" - cujo primeiro título, dos Buenos, apareceu em 1742 -, viajou para Portugal em 1755, com a finalidade de reunir documentos em relação aos direitos de posse da Capitania de São Vicente, encarregado de defender os direitos que o Conde de Vimeiros, considerado descendente legítimo de Martim Afonso de Souza, considerava ter sobre esse território. Na metrópole permaneceu por dois anos, tendo-lhe então ocorrido sérios infortúnios: ficou gravemente doente e, em decorrência do incêndio ocorrido durante o terremoto de Lisboa, perdeu tudo o que tinha, inclusive os manuscritos da "Nobiliarquia Paulistana", então em preparo. Mas, uma vez restabelecido, "passou a conviver com historiadores e linhagistas, a freqüentar arquivos, cartórios e bibliotecas" a fim de reiniciar seu trabalho genealógico (AMARAL, 1980, pp. 451-2).

Beneficiado pela intervenção do governo ilustrado, deixou Portugal "com a nomeação, providenciada pelo Marquês de Pombal, para o cargo de tesoureiro-mor da Bula da Santa Cruzada nas Capitanias de São Paulo, Goiás e Mato Grosso. No momento da reordenação administrativa da Capitania, foi investido no cargo de guarda-mor das minas na Comarca de São Paulo, acumulando-o com o anterior" (AMARAL, 1980, pp. 451).

De volta a São Paulo, continuou a trabalhar na "Nobiliarchia, paulistana historica e genealógica", "composta segundo a lição dos cartórios assim seculares como eclesiásticos da Capitania de São Paulo e suas vizinhas" (TAQUES, 1953, folha de rosto), tratando das mais antigas famílias da Capitania de São Paulo, pois, como mostrou Pedro Garcez Ghirardi (2009) na época, o termo "paulistano" não tinha conotação geográfica, mas antes designava status social. Em 1768, concluiu a "Notícia histórica da expulsão dos jesuítas do collegio de São Paulo".

O historiador teve papel destacado no governo do Morgado de Mateus: "foi membro do Conselho Consultivo do Governador e tomou parte ativa na questão de limites entre as capitanias de São Paulo e Minas Gerais...”, exercendo ainda funções judiciárias, na qualidade de "procurador da Câmara da cidade de São Paulo e das vilas de Pindamonhangaba e Cananéia". Sua ação se desdobrou, portanto, entre a capital, o interior e o litoral. Mas, em razão de problemas financeiros e burocráticos - decorrentes de acusação de desvirtuamento em benefício próprio dos recursos que administrava - teve seus bens sequestrados. Nesse contexto, procurou o Morgado "auxilia-lo com missão intelectual, encarregando-o de escrever a informação sobre as Minas de São Paulo" (AMARAL, 1980, p.451-2), ${ }^{11}$ e ordenando ainda que 
O Sargento Mor Pedro Taques por serviço de S. Mag. declare tudo o que souber a respeito do estado das Aldeyas desta Capitania, as ordens Reaes que tem havido a respeito das suas terras e governo, e enfim tudo aquillo que alcançar o seu conhecimento e julgar precizo se conserve nesta secretaria para todo o tempo constar (DI, VOL. XXXIII, p.108).

Ao mesmo tempo, concluía Pedro Taques a "História da Capitania de São Vicente", obra de encomenda particular, que constituiu "sobretudo um arrazoado jurídico para provar os direitos do Conde de Vimeiro à capitania de São Paulo..." (TAUNAY, s/d/p, p.20).

Estava então com 58 anos de idade e, doente, fez em 1774 sua segunda viagem a Portugal. Faleceu três anos depois, em São Paulo. De acordo com Taunay (s/d/p, pp. 10- 15), "trabalhador infatigável, imenso produziu Pedro Taques”. Mas, pelos cálculos do autor, cerca de dois terços de sua obra teriam desaparecido.

Em que pesem as limitações da vivência cultural letrada na Capitania de São Paulo, a obra desses historiadores voltou-se para sua Capitania de nascimento, o que é significativo como postura específica de valorização de um território. Nas "Memórias para a história da capitania de São Vicente", centrada no século XVI, Frei Gaspar tratou da fundação das capitanias de São Vicente e de Santo Amaro, detalhando-se, para a primeira, a fundação da "vila do Porto de Santos", da “Cidade de São Paulo" e da Vila Nossa Senhora da Conceição de Itanhaem”. Nela se expõem pormenorizadamente os acontecimentos, com base nas descrições geográficas, registros cartoriais e documentos de ordem vária, criticamente integrados com a bibliografia que envolvesse as temáticas tratadas na obra. Da mesma forma trabalhou Pedro Taques, quer reunindo documentação para a sua "Nobiliarchia", quer nos trabalhos com objetivos administrativos encomendados pelo Morgado e, também, nos seus demais escritos, ainda que com o propósito de defender interesses de indivíduos particulares. Servindo-se das atribuições administrativas inerentes aos cargos que exercia, Pedro Taques se valia de seus subordinados para a coleta de informações: "mandavam-lhe os seus cobradores nas villas das três capitanias informações sobre informações, aproveitadas pelo historiador no exhaustivo trabalho da reconstrucção de sua enorme Nobiliarchia..." (TAUNAY, 1923, p. 100).

No que se refere a sua formação primeira, ambos os historiadores realizaram seus estudos iniciais com os jesuítas. Contudo, bem antes da ascensão de Pombal e da expulsão dos jesuítas da América Portuguesa, Frei Gaspar optara pelos beneditinos para se ordenar sacerdote. Por sua vez, embora Pedro Taques tenha feito o curso de artes no Colégio dos Jesuítas em São Paulo, recebendo 


\section{Marisa Saenz Leme}

o título de "mestre em artes", no seu trabalho historiográfico voltou-se contra o tipo de cultura incentivada pelos padres de Santo Inácio.

$\mathrm{Na}$ "Notícia histórica da expulsão dos jesuítas do collegio de São Paulo" atacou a atuação dos membros da Companhia, sobretudo no que se refere a sua forma de dominação política, em concorrência com o estado monárquico e sobreposta aos interesses mineradores - escravistas dos paulistas. Dessa maneira, endossou Pedro Taques as posições dos conterrâneos e historiou a expulsão dos irmãos da ordem da Capitania, em 1640 e em 1687, enquanto decorrência de procedimentos avaliados como culposos. Mas seu posicionamento apoiou-se na interpretação que fez de documentos constituídos, sobretudo pelas representações dos paulistas, pelas posturas governamentais e pelos acordos estabelecidos entre jesuítas e representantes das populações do Rio de Janeiro e de São Paulo.

Por vários indícios intelectuais, as obras de Frei Gaspar e Pedro Taques podem ser situadas no escopo da Ilustração, sobretudo ao se considerarem as especificidades dessa vivência na Colônia Brasil. Embora com recurso ao imaginário, filhos das mais antigas e abastadas famílias paulistas, com posturas aristocráticas, valorizando a nobiliarquia com vistas ao engrandecimento do passado para o que buscaram contrapor a imagem de uma civilização dos bandeirantes à "lenda negra" contra eles construída pelos jesuítas - os recursos intelectuais empregados pelos primos foram, de um modo geral, modernos. Fizeram eles parte da inovação, senão instaurada, amplamente incentivada no projeto historiográfico da "Academia dos Renascidos", entre outros fatores, ao se valorizar o método crítico de confronto documental e bibliográfico na produção de memórias e obras historiográficas (SILVA, 1986, pp. 29-32). Nesse sentido, foram esses historiadores paulistas particularmente críticos (TAUNAY, s/d/p, p.32ss) da obra de Rocha Pitta, senhor de terras baiano, um dos fundadores da Academia dos Esquecidos, que vigorou entre 1724 e 1725. Publicara ele, em 1730, uma "Historia da América Portuguesa, desde o seu descobrimento até o anno de 1724". Apesar do seu recurso a documentos, escrevera nos moldes de uma historiografia providencialista (KANTOR, 2004, pp.202-8).

Culturalmente, em que pese a importância do legado jesuítico, no que se refere aos estudos geográficos e etnográficos, bem como ao trabalho arquivístico e de organização de bibliotecas, observa-se na época o abandono dos valores, métodos e concepções intelectuais dominantes ${ }^{12}$ na Companhia, entre outros fatores, nas suas consequências para o entendimento da história. Colocaram-se em questão as relações entre os níveis teológicos e laicos do conhecimento, as 
hierarquias entre memória, repetição, tradição e questionamento crítico, bem como as interdependências entre Igreja e Estado (FALCON, pp.424ss).

$\mathrm{Na}$ avaliação de Maria Beatriz Nizza da Silva, (1986, p.30) "a idéia subjacente às Memórias é a de que não se pode aceitar como verdadeiro aquilo que até então se escrevera sobre o Brasil, pois, a descoberta e publicação de novos documentos (fruto do labor acadêmico, quer em Portugal, quer no Brasil) vinham sem dúvida questionar a veracidade daquelas narrativas". Por sua vez, a "Nobiliarchia" de Pedro Taques, fruto de "uma vida atrás de documentos esparsos por vários Arquivos da América e de Portugal" é contemporaneamente avaliada como "fonte imprescindível ao estudo da sociedade paulista do Setecentos" (SOUZA, 2006, p. 145). O linhagista, ao lado do primo Frei Gaspar, teria sido na Capitania de São Paulo a "primeira figura que teve noção de vida literária e de sua importância no processo da cultura" (PINHEIRO, 1975, p.96), pois, na avaliação desse autor, figuras anteriores de destaque intelectual, nascidas na Capitania, estariam culturalmente ligadas apenas a Portugal.

Por seu lado, 'Mestre de Filosofia e Teologia", Frei Gaspar, no mosteiro fluminense dos beneditinos, ministrou cursos que, entre outros fatores, distinguiram-se pela "inovação dos métodos do ensino", tendo provavelmente redigido, em dois tomos, um tratado do curso de filosofia que ministrou em 1748 (TAUNAY, 1975, p. 10). ${ }^{13}$ Na condição de Abade do Rio de Janeiro, entre várias iniciativas intelectuais como o enriquecimento da biblioteca, realizou pessoalmente os trabalhos do arquivo, refazendo "os livros do Tombo e deixando principiada uma história cronológica de todos os documentos pertencentes às propriedades do mosteiro" (TAUNAY, 1975, p.12).

No que diz respeito ao plano das relações entre igreja e estado, contrariamente aos padres de Santo Inácio, esses historiadores paulistas assumiram a perspectiva de soberania do estado centralizado e laico, tal qual se expressa nas formulações ilustradas, o que se evidencia no teor das suas obras e numa visão de conjunto dos seus dados biográficos. Observe-se ainda que objetivos do estado laico e defesa de direitos considerados senhoriais formavam uma tensão pertinente aos embates jurídicos da época das luzes. O que, no caso da Colônia Brasil e em São Paulo, apresentouse grandemente na questão das terras, na disputa entre sua apropriação pelo estado ou pelos que se diziam herdeiros dos donatários originais, temas grandemente abordados pelos primos historiadores.

Naquele contexto colonial, é importantíssimo não se tomar a religiosidade - tão valorizada por Taunay enquanto atributo revelador do tradicionalismo de Taques - como contrária ao espírito da Ilustração vigente em Portugal e na sua colônia americana. Há que diferenciar, nesse sentido, a 
predominância jesuítica, avessa às novas posturas filosóficas, das concepções teológicas de outras ordens religiosas, passíveis de se articularem com o experimentalismo dos novos tempos (MACHADO NETO, pp.103ss; pp. 220ss).

Num outro escopo, articulado com o desenvolvimento de posturas críticas no interior da América Portuguesa, mas já distinto dos marcos do iluminismo em si, o trabalho desses historiadores paulistas inseriu-se num processo de valorização regional do território, importante nas manifestações nativistas do último terço do século XVIII (CÂNDIDO, 1967, p. 170).

Ao que se indica, o sentimento nativista aparece de fato bastante fortalecido em São Paulo, no período em apreço. Apresentou-se claramente na academia literária em homenagem a José Bernardo de Lorena, quando o Governador foi saudado pelos "infinitos benefícios, que esta República Pauliense tem recebido..." $\mathrm{Na}$ fala de encerramento da "Academia", elogiaram-se os “ilustres Acadêmicos, que penetrados do verdadeiro espírito do Patriotismo, procuraram imortalizar a honra do Pauliense Império ACADEMIA em homenagem a Bernardo José de Lorena, pp. 57 e $65)$.

\section{Sopros de inovação}

Em que pesem os naturais limites da situação colonial - o "viver em colônias", nos dizeres de Vilhena (1987, p.5) - e, frise-se, colônia de matriz ibérica - observa-se, no panorama cultural da capitania de São Paulo, na segunda metade do século XVIII, o desenvolvimento de um conjunto de atividades artísticas e literárias que, quantitativa e qualitativamente diversificadas, imprimiram no contexto da época uma diretriz inovadora em boa parte das suas realizações. Se isto não foi verdadeiro para o campo especificamente literário, que se manteve preso a uma vivência oficial, prenhe de barroquismo, os sopros inovadores apresentaram-se na historiografia, na música, na arquitetura e, em certa medida, também nas artes plásticas.

Sempre tendo em mente os focos da Ilustração portuguesa e sua vivência numa área colonial como a da Capitania de São Paulo, observa-se uma renovação dos parâmetros até então dominantes, de inspiração jesuítica. Vivência ilustrada essa que ocorria nas áreas então renovadas da Capitania, como Santos e Capital, ou expandidas, como Itu e adjacências, em que houve uma expansão do elemento urbano, propício à circularidade cultural e ao desenvolvimento de um segmento social - ainda que quantitativamente diminuto, qualitativamente fundamental - apto à assimilação das posturas que se poderiam designar como "iluministas". Segmento esse que por 
seus hábitos de sociabilidade, leituras, e produção artística, ultrapassou os limites de uma cultura de centralidade religiosa para desenvolver dimensões específicas de laicidade.

$\mathrm{Na}$ sequência, a presença da Corte no Rio de Janeiro naturalmente incentivou a disseminação dessas tendências já presentes na Capitania. Às vésperas da Independência, havia em São Paulo, conforme Augustin Wernet (1986, p. 343), uma "minoria ilustrada" - constituída por funcionários públicos, fazendeiros, comerciantes, médicos e advogados - em meio a uma população rural alheia ao que se passava e que seguia passivamente os chefes locais. As "grandes vilas" contrastariam significativamente nesse quadro com grupos passíveis de assimilar as ideias liberais.

Nessa minoria misturavam-se - de acordo com o que aconteceu de um modo geral entre as elites ilustradas europeias - as atividades artísticas, científicas e políticas. Pode-se distinguir entre os seus componentes traços principais, dominantes, nas suas atividades. Mas em algum ponto elas se imbricaram, no histórico da existência cultural e política da época.

\section{Referências bibliográficas}

AMARAL, Antonio Barreto do. Dicionário da História de São Paulo. Governo do Estado de São Paulo, Coleção Paulística, 1980.

ANDRADE, Mário. Padre Jesuíno do Monte Carmelo. São Paulo: Martins, 1963.

BELlOTTO, Heloísa Liberali. Autoridade e Conflito no Brasil Colonial: o Governo do Morgado de Mateus em São Paulo. São Paulo: Secretaria de Estado da Cultura/ Conselho Estadual de Artes e Ciências Humanas, 1979.

BINDER, Fernando Pereira; CASTAGNA, Paulo. Teoria musical no Brasil: 1734-1854. Depto. De Artes da UFPr. Revista Eletrônica de Musicologia. Vol. 1.2/Dezembro de 1996.

CÂNDIDO, Antonio. Formação da Literatura Brasileira: momentos decisivos. 5a ed.: Belo Horizonte/Itatiaia; São Paulo/ EDUSP, 1975, vol. 1.

CASTAGNA, Paulo. Música na América portuguesa. In: MORAES, José Geraldo Vinci; SALIBA, Elias Thomé (orgs.), História e Música no Brasil. São Paulo: ALAMEDA, 2010, pp. 35-76).

Cia. Editora Nacional, 1967.

Literatura e sociedade: estudos de teoria e história literária. São Paulo:

CASTAGNA, Paulo; GABRIEL, Vitor. Introdução ao CD: Música na catedral de São Paulo _ vol. 1: Obras do Arquivo da Cúria Metropolitana de São Paulo. Brasilessentia Grupo Vocal/Orquestra de Câmara da UNESP, 2001. 
CHARTIER, Roger. A história cultural entre práticas e representações. Lisboa: DIFEL/Rio de Janeiro: Bertrand Brasil,1990.

. A ordem dos livros: leitores, autores e bibliotecas na Europa entre os séculos XVI e XVII. Brasília: Editora da Universidade de Brasília, 1994 (ensaio "Figuras do autor", pp. 33 a 65).

CUNHA, Norberto Ferreira da. Elites e académicos na cultura portuguesa setecentista. Lisboa: Imprensa Nacional - Casa da Moeda, 2001.

DERNTL, Maria Fernanda. Método e Arte: criação urbana e organização territorial na capitania de São Paulo, 1765-1811. Tese de Doutorado, Faculdade de Arquitetura e Urbanismo (FAU), Universidade de São Paulo (USP), 2010.

DIAS, Maria Odila Leite da Silva. Aspectos da ilustração no Brasil. Revista do Instituto Histórico e Geográfico Brasileiro, vol. 278, jan./mar. 1968, pp. 105 a 170. Trabalho posteriormente republicado em A interiorização da metrópole e outros estudos. São Paulo: Alameda, 2005.

DOMÍNIO PÚBLICO. Aliança Brasileira de Cooperação para divulgação de obras de Domínio Público, 27/09/2011.

DUPRAT, Regis. Música na Sé de São Paulo colonial. Sociedade Brasileira de Musicologia/Paulus, 1995. Texto introdutório ao CD Música do Brasil Colonial. André da Silva Gomes. Brasilessentia Grupo Vocal e Orquestra.São Paulo: PAULUS, 1995.

. Entrevista à Folha de São Paulo, 15-01-2007.

FALCON, Francisco José Calazans. A Época Pombalina (Política Econômica e Monarquia Ilustrada). São Paulo: Ática, 1982.

FONDA, Enio Aloísio. A Academia dos felizes e a poesia latina de Frei Antônio de Sant’Ana Galvão, religioso franciscano. Revista do Instituto de Estudos Brasileiros, n.13, 1972.

GHIRARDI, Pedro Garcez. Palavras em mutação: a busca dos paulistas e o achado de Pedro Taques. Disponível em: http:/www.hottopos.com/videtur29/pedrogg.htm, acesso 16/09/2009.

GUERRA, François Xavier. Modernidad e independências:Ensayos sobre las revoluciones hispânicas. México, D.F.: FONDO DE CULTURA ECONOMICA, 1993 (Cap II: La modernidad absolutista).

HOLANDA, Sérgio Buarque de. Apresentação de SILVA, Maria Beatriz Nizza da, Cultura $e$ sociedade no Rio de Janeiro ( 1808-1821). São Paulo: Editora Nacional: Brasîlia, INL, 1977.

KANTOR, Íris. Esquecidos e Renascidos:Historiografia Acadêmica Luso-Americana (1724-1759). São Paulo/HUCITEC; Salvador: CENTRO DE ESTUDOS BAIANOS/UFBA, 2006.

A disputa da América na historiografia brasîlica: D. Domingos Loreto Couto e frei Gaspar da Madre Deus. In: VAINFAS, Ronaldo; SANTOS, Georgina Silva do; NEVES, Guilherme Pereira 
das (orgs.). Retratos do Império: Trajetórias individuais no mundo português nos séculos XVI a XIX. Niterói: EdUFF, 2006.

LIMA, Manoel de Oliveira. D. João VI no Brasil. 2ª ed.: Rio de Janeiro, José Olympio, 1945, $1^{\circ}$.

LYRA, Maria de Lourdes Viana.A Utopia do poderoso Império. Rio de Janeiro: Sette Letras, 1994.

MACHADO NETO, Dionísio. Administrando a festa: Música e Iluminismo no Brasil Colonial. Tese de Doutorado, Escola de Comunicação e Artes (ECA), Universidade de São Paulo (USP), 2008.

MARIZ, Vasco. História da Música no Brasil. 2a . ed.: Rio de Janeiro, Civilização Brasileira, 1983.

ORBINO, Nise Poggi e DUPRAT, Regis; CHASE, Gilbert. O estanco da música no Brasil colonial In Anuário, University of Texas Press, Vol. 4, 1968, pp. 98-108.

PINHEIRO, Péricles da Silva. Manifestações literárias em São Paulo na época colonial. São Paulo: Academia Paulista de Letras, 1975.

RODRÍGUEZ O, JAIME E. La independencia de la América Española. México D.F., FONDO DE CULTURA ECONÓMICA,1996, Cap.II, La revolución en el mundo español’, pp. 55 a 98.

SILVA, Maria Beatriz Nizza da. Frei Gaspar da Madre Deus ou a controvérsia da história. Revista do Instituo Histórico e Geográfico de São Paulo, vol. 56, 1986, pp.29-32.

. Ser nobre na colônia. São Paulo: Editora UNESP, 2005.

SILVA, Ana Rosa Cloclet da. Inventando a Nação: Intelectuais e Estadistas Luso-Brasileiros na Crise do Antigo Regime Português (1750-1822). São Paulo: HUCITEC/ FAPESP, 2006.

SOUZA, Laura de Mello e. O Sol e a sombra. São Paulo: Companhia das Letras, 2006.

TAUNAY, Affonso de E. Súmula Biográfica. In: MADRE DE DEUS, Frei Gaspar da. Memórias para a história da capitania de São Vicente. Belo Horizonte: Itatiaia, 1975 ,

- Pedro Taques e sua obra. Introdução à edição conjunta de LEME, Pedro Taques de Almeida Paes. Informação sobre as minas de S. Paulo e A expulsão dos jesuítas do collegio de S.Paulo. São Paulo: Companhia Melhoramentos de S. Paulo, s/d/p.

. Pedro Taques e seu tempo: estudo de uma época. São Paulo: Diário Oficial, 1923, p.100.

TOLEDO, Benedito Lima de. Frei Galvão: um arquiteto paulista. In TIRAPELI, Percival (org.) Arte Sacra Colonial, pp.34-41. UNESP/Imprensa Oficial, 2001.

TRINDADE, Jaelson Britan de; CASTANHA, Paulo. Música pré-barroca luso-americana: o grupo de Mogi das Cruzes. Revista Eletrônica de Musicologia. Depto. de Artes da UFPr, 1.2/ Dezembro de 1996. 
TELAROLLI JUNIOR, Rodolpho. A secularização do registro dos eventos vitais no Estado de São Paulo". Revista Brasileira de Estudos de População. Campinas: Associação Brasileira de Estudos Populacionais, 1993, pp. 145-156.

TIPARELI, Percival; SALOMÃO, Myriam. Pintura colonial paulista. In: TIPARELI, Percival (org.). Arte sacra colonial. UNESP/Imprensa Oficial, 2001.

TORRÃO FILHO, Amílcar. Em Utilidade do Bem Comum: Usos e Conflitos do Espaço Público em São Paulo (1765-1775). In: Politeia: História e Sociedade. Revista do Departamento de História da Universidade Estadual do Sudoeste da Bahia, v. 6, n.1, 2006. Vitória da Conquista, BA: Edições Uesb, 2006.

. Paradigma do caos ou cidade da conversão? São Paulo na administração do Morgado de Mateus (1765-1775).São Paulo: FAPESP/Annablume, 2007.

TRINDADE, Jaelson Bitran. Música colonial paulista: o grupo de Mogi das Cruzes. Revista do Patrimônio Histórico e Artístico Nacional. Rio de Janeiro, n. ${ }^{\circ}$ 20, 1984.

WERNET, Augustin. O processo de Independência em São Paulo. In: MOTA, Carlos Guilherme. 1822: Dimensões. São Paulo: Perspectiva, 1986.

\section{Fontes}

\section{Manuscritas}

RELAÇÃO das festas públicas que na cidade de São Paulo fez o ilustríssimo e excelentíssimo senhor dom Luiz Antonio de Souza Botelho Mourão, no dia 19 de agosto, dia de São Joaquim, dia 21 para comemorar o aniversário de dom José, príncipe da Beira, o dia de são Luiz e a conquista de Tibagi (IEB, Coleção Yan de Almeida Prado, códice 39).

\section{Impressas}

ACADEMIA em homenagem a Bernardo José de Lorena. Em: CASTELO, José Aderaldo. $O$ Movimento academicista no Brasil 1641-1820/22. Secretaria da Cultura, Ciência e Tecnologia. Coleção de Textos e Documentos. Imprensa Oficial do Estado, 1969.

DOCUMENTOS INTERESSANTES PARA A HISTÓRIA E COSTUMES DE SÃO PAULO. ARCHIVO DO ESTADO DE S.PAULO.S.PAULO

VOL. XXIII (1896). Correspondência do Capitão-General Dom Luiz Antonio de Souza Botelho Mourão 1766-1768.

1. Carta ao Conde de Oeyras, São Paulo, 23 de Dezembro de 1766, pp. 1 a 10.

2. Carta para o Snr. Conde de Cunha Vice Rey, São Paulo 4 de Julho de 1767, pp. 182-183.

3. Carta para o Conde de Oeyras, São Paulo 3 de Julho de 1767, pp. 187-190.

4. Carta a S.Magestade Rey de Portugal , São Paulo, $1^{\circ}$.de Dezembro de 1767, pp.250-256

5. Carta para a Secretaria de Estado, São Paulo, 30 de Janeiro de1768, pp. 374 a 377.

6. Idem, São Paulo, 31 de janeiro de 1768, pp. 377 a 382.

VOL. XXXIII (1901). Ordens, Portarias e Bandos de D. Luiz de Souza (1771-1775).

1. Portaria sobre o divertimento das operas, S. Paulo, 20 de Novembro de 1772, p.79. 
2. Portaria mandando prevenir desordens durante a festa de S. Gonçalo em Santos, S.Paulo, a 27 de Dezembro de 1772, pp. 82-3.

3. Portaria para o Sargento Mor Pedro Taques declarar tudo o que há a respeito das Aldeyas desta Capitania, S. Paulo a 15 de Novembro de 1772, p. 108.

VOL. LVI (1937). Correspondência oficial do Capitão General José da Franca e Horta (1804-1806). 1. Ao Juiz Ordinário de Cannanéa, S. Paulo, 16 de Abril de 1804, p. 69-70.

VOL. LVII (1937). Correspondência oficial do Capitão General José da Franca e Horta (1806 1810).

1. Ordens sobre as festas a se realizarem por ocasião da chegada do Príncipe Regente, S. Paulo, a 10 de Março de 1808, pp. 253-256.

2. Para os Professores de Philozofia, Retórica, e Gramática, S. Paulo, a 10 de março de 1808, p. 255.

VOL. LXXIII. Ofícios do Capitão-General Dom Luiz Antonio de Souza Botelho Mourão 17651766.

1. Carta ao Conde de Oeyras, São Paulo, 11 de Dezembro de 1766, p. 66.

MADRE DE DEUS, Frei Gaspar da. Memórias para a história da capitania de São Vicente. Belo Horizonte: Itatiaia, 1975.

TAQUES, Pedro ( Pedro Taques de Almeida Paes Leme). Nobiliarchia paulistana historica e genealógica.São Paulo: Martins, 1953.

. Informação sobre as minas de São Paulo. São Paulo: EDITORA COMPANHIA MELHORAMENTOS DE S.PAULO, s/d/p.

- A expulsão dos jesuítas do collegio de S.Paulo EDITORA COMPANHIA MELHORAMENTOS DE S.PAULO, s/d/p.

VILHENA, Luís dos Santos. Pensamentos políticos sobre a Colônia. (Com introdução de Emanuel Araújo). Rio de Janeiro: Arquivo Nacional, 1987.

\section{Discografia}

Brasilessentia Grupo Vocal e Orquestra. Música do Brasil Colonial. André da Silva Gomes. São Paulo: PAULUS, 1995

Brasilessentia Grupo Vocal e Orquestra. Orquestra de Câmara da UNESP. Vitor Gabriel regente. Música na Catedral de São Paulo. Obras do Arquivo da Sé Cúria Metropolitana de São Paulo.

KANJI, Ricardo. Orquestra e Coro Vox Brasiliensis. História da Música Colonial Brasileira, vol.1.

\section{Notas}




\section{Marisa Saenz Leme}

1 Observe-se que o termo "caipira" foi utilizado neste texto na sua designação comum, para indicar genericamente como
os paulistas eram vistos na época em apreço, sem as conotações sociológicas da expressão "cultura caipira", utilizada
por Antonio Cândido na análise de comunidades rurais paulistas encontráveis entre os séculos XIX e XX. Para tanto ver: Os parceiros do Rio Bonito, Editora José Olympio, São Paulo, 1957.

2 De acordo com as pesquis as realizadas pela autora, essa denominação "parece originar-se do local onde se instalou" a referida instituição (LYRA, 1994, p. 83 ).

${ }^{3}$ Como, por exemplo, a Missa a Oito Vozes, a Missa a 5 vozes, e os Ofertórios. As composições de André da Silva Gomes passaram a ser resgatadas por Regis Duprat a partir do início da década de 1960, tendo permanecido até então praticamente desconhecidas. De acordo com esse musicólogo, apenas a obra do Padre José Maurício, com 220 peças, foi maior que a de André da Silva Gomes (DUPRAT, 2007). Como listado em "discografia”, existem CDs de gravação nacional de ótima qualidade, com parte das obras desse compositor.

${ }^{4}$ Lembre-se, porém, que na própria capital do Vice-reino a quantidade de músicos compositores era comparativamente pequena. Destacava-se na cidade o Padre José Maurício, por muito tempo praticamente o único músico colonial brasileiro com visibilidade historiográfica (CASTAGNA, 2010, pp.68ss).

${ }^{5}$ Não se sabe exatamente a data de nascimento de Frei Galvão, "por se haver perdido o livro de Registro de Batismos da Matriz de Santo Antônio (de Guaratinguetá)... relativo aos anos de 1729-1740”... Mas sabe-se que "recebeu o Batismo" nessa mesma Matriz no ano de 1739, “conforme consta de outros documentos canônicos"(FONDA, 1972, p.73).

${ }^{6}$ Posteriormente, o padre Jesuíno improvisou-se arquiteto, tendo sido responsável pela construção do convento dos Padres do Patrocínio, que fundara em decorrência da marginalização por ele sofrida no interior da igreja, pois, ordenado padre, não conseguia realizar o seu desejo de pertencer à ordem dos carmelitas, para a qual decorara a igreja de Itu. Também o padre Feijó agregou-se aos padres do Patrocínio (ANDRADE, 1963, pp.59ss).

${ }^{7}$ De acordo com o consagrado autor, as academias estabelecidas na Colônia Brasil no século XVIIII, sobretudo na sua segunda metade, diferenciaram-se entre as "permanentes, temporárias e ocasionais", sendo as últimas em "número bem maior e ainda não fixado". A Academia dos Felizes paulista foi homônima de outra, fundada no Rio de Janeiro em 1736, mais conhecida e estudada (CÂNDIDO, 1975, p.78).

${ }^{8}$ Esse documento, da coleção Yan de Almeida Prado, foi, ao que se indica, por primeiro utilizado por Arthur da Motta, em História da Literatura Brasileira (São Paulo: Companhia Editora Nacional, 1930, pp. 29-31; pp. 218-19), tendo sido bastante referido pelos autores que estudaram a vida cultural da Capitania, em suas diversas dimensões.

${ }^{9}$ Os significados da sátira no mundo ibérico do século XVII foram de modo muito sagaz decodificados por João Adolfo Hansen (A sátira e o engenho: Gregório de Matos e a Bahia do século XVII. $2^{\mathrm{a}}$ ed.: Cotia: ATELIÊ EDITORIAL /Campinas: EDITORA da UNICAMP, 2004): "o código de honra reitera a hierarquia e faz propaganda dela, quando efetua os vícios como ridículos, imorais e irracionais...(p.56) "Quando critica fidalgos locais, a sátira desqualifica-os como vulgo em nome de valores discretos que postula como distintivos dos fidalgos dirigentes, que se enunciam como verdadeiros" (p.94).

10 Desapareceu praticamente toda a corres pondência e parte dos manuscritos historiográficos de Frei Gaspar, entre eles, o que provavelmente teria sido o $3^{\circ}$. Livro das Memórias. Entre seus outros trabalhos, destaque-se: Dissertação $e$ Explicação sobre terras de contenda entre o Mosteiro de São Bento e o Convento do Carmo, em Santos (1746) - libelo escrito para defender o que se consideravam direitos do mosteiro beneditino de Santos à posse do santuário de Montserrat - contestada pelos carmelitas - em que, de acordo com Taunay, o autor revelou "profundo conhecimento da história territorial quinhentista de São Paulo"; Notícia dos anos em que se descobriu o Brasil e das entradas das Religiões e suas Fundações (1784): este, sob ordens, no cargo de cronista da ordem (TAUNAY, 1975, pp.20-26).

11 Pedro Taques apaixonara-se por mulher de quem era "procurador universal" e, embora estivesse prosperando financeiramente, emprestou-lhe dinheiro além de suas posses, utilizando o da tesouraria: "foi denunciado ao comissário da Bula, suspenso de suas funções e obrigado a entregar todos os livros de assentos e os de seus tesoureiros...", o que lhe valeu novamente a perda dos seus bens, na busca de reduzir o débito. Mas o Morgado, convencido de ser ele vítima de injusta perseguição, "confirmou-o no posto de guarda-mor das Minas." Por sua vez, em 1774, "obteve meios" para ir a Portugal resolver seus problemas com o Tribunal da Bula (AMARAL, 1980, pp. 481-2).

${ }^{12} \mathrm{O}$ que não exclui - pelo contrário, compreende - a existência de fortes debates intelectuais no interior da ordem, bem como a existência de elementos individualmente dissidentes das perspectivas nela hegemônicas.

${ }^{13}$ Os originais que confirmam a existência do tratado são constituídos por "nume rosas laudas" encontradas no Arquivo do Mosteiro de São Bento de São Paulo ( $1^{\circ}$. Tomo), e um manuscrito encontrado no arquivo do mosteiro de Olinda ( $2^{\circ}$. Tomo) (TAUNAY, 1975, pp.10 e 23). 
Recebido em agosto de 2011.

Aprovado em dezembro de 2011. 